Revista Complutense de Historia de América

ISSN: $1132-8312$

http://dx.doi.org/10.5209/RCHA.56731

\title{
El saqueo de los ornamentos y las alhajas sagradas en las Guerras de Independencia de Colombia: entre la represión política y la devoción religiosa ${ }^{1}$
}

\author{
Roger Pita Pico ${ }^{2}$
}

Recibido: 23 de agosto de 2015 / Aceptado: 23 de diciembre de 2015

Resumen. En el marco de la celebración del Bicentenario de la Independencia de las naciones hispanoamericanas, este artículo tiene por objeto analizar el saqueo, la ocultación, la transformación y la destrucción de las alhajas y ornamentos de iglesias y conventos durante el conflicto político y militar de las guerras de emancipación de la Nueva Granada. Así entonces, durante estos agitados años estas piezas sagradas estuvieron inmersas en un ambiente signado por la polarización política, la devoción religiosa y el afán de republicanos y españoles por conseguir recursos para la guerra. Bastante complejas e inciertas resultaron las reclamaciones de las iglesias por recuperar sus piezas sagradas en medio de una atmósfera marcada por la secularización y la tensión entre el poder político y el poder eclesiástico. Palabras clave: Ornamentos; alhajas; robo; incautación; guerra; Iglesia; Independencia; Colombia; siglo XIX.

\section{[en] The Looting of Sacred Ornaments and Jewels in the Wars of Independen- ce of Colombia: between Political Repression and Religious Devotion}

\begin{abstract}
In the framework of the bicentennial celebration of the Independence of the Hispano-American nations, this article aims to analyze the looting, concealment, transformation and destruction of jewelry and ornaments of churches and convents during the political and military conflict in the wars of emancipation of Colombia. During those hectic years, these sacred pieces were immersed in a context marked by political polarization, religious devotion and the desire of Republicans and Spaniards to acquire resources for the war effort. Quite complex and uncertain were the intentions of the churches to reclaim their sacred pieces in a milieu marked by secularization and tensions between the political and ecclesiastical powers.
\end{abstract}

Keywords: Ornaments; Jewelry; Theft; Seizure; War; Church; Independence; Colombia; 19th Century.

Sumario. 1. Introducción. 2. Robos y saqueos en medio de la campaña militar. 3. Las alhajas confiscadas. 4. Prevenciones, juzgamientos y omisiones. 5. Las contribuciones voluntarias. 6. El destino de las alhajas. 7. La lucha por la recuperación de las alhajas. 8. Conclusiones. 9. Referencias bibliográficas.

\footnotetext{
$1 \quad$ El presente artículo es resultado del proyecto de investigación que de manera independiente adelanta el autor sobre Estado e Iglesia en Colombia en los primeros años de la República: los dilemas y entresijos del proceso de construcción nacional.

2 Academia Colombiana de Historia (Colombia)

E-mail: rogpitc@hotmail.com
} 
Cómo citar: Pita Pico, R. (2017) El saqueo de los ornamentos y las alhajas sagradas en las Guerras de Independencia de Colombia: entre la represión política y la devoción religiosa, en Revista Complutense de Historia de América 43, 179-202.

\section{Introducción}

Desde tiempos coloniales, la Iglesia ocupaba un lugar preponderante en la América hispánica. Ampliamente reconocido era su poder económico, su fortaleza institucional, su influencia moral, su aceptación social y su presencia en los rincones más apartados $^{3}$. La sociedad mostraba una profunda religiosidad popular reflejada en la devoción a sus imágenes sagradas, en las fiestas religiosas y en las romerías.

Los ornamentos y las alhajas sagradas ${ }^{4}$ eran parte fundamental del culto divino desde los primeros años del dominio colonial. En las Constituciones Sinodales, promulgadas en 1606 por el arzobispo de Santa Fe don Bartolomé Lobo Guerrero, se dispuso que para la doctrina de los indios se necesitaban al menos 40 ornamentos, dentro de los cuales se incluía un relicario de plata, un cáliz de plata con su patena, unas vinajeras de plata y unas crismeras, elementos que debían ser proveídos por los encomenderos o por las autoridades españolas 5 .

A medida que se fue extendiendo la presencia de la Iglesia en el territorio neogranadino, a través de la erección de templos y conventos, asimismo se incrementó el número de alhajas sagradas cuyo propósito era fortalecer en los feligreses el sentido de la devoción católica. Santos patronos e imágenes sagradas fueron delicadamente adornados con multitud de joyas y piedras preciosas con el fin de imprimirles más esplendor.

En el siglo XVII se vivió en el virreinato de Nueva España un florecimiento del arte de la platería debido a las riquezas encontradas en las minas, observándose ya por estos años alguna influencia artística indígena. Bajo el impulso de la dinastía borbónica, para la siguiente centuria este arte alcanzó su máximo desarrollo en razón a la creciente extracción de metales preciosos y al auge de renovación artística, lo cual se vio reflejado en el aumento de talleres ${ }^{6}$.

Particularmente, en la Nueva Granada abundaron metales y piedras preciosas, tales como: oro, plata, esmeraldas, amatistas, granates, perlas, tagua y carey, lo cual favoreció el desarrollo de la orfebrería, especialmente en la villa de Mompós y en la gobernación de Popayán en el siglo XVIII. Las joyas registradas en los inventarios de las iglesias, en las dotes matrimoniales y en los testamentos permiten evidenciar la destreza de los maestros dedicados a este arte 7 . Aunque muchas de las alhajas sagradas fueron encargadas por los miembros del clero, otras se elaboraron gracias al esfuerzo y aporte mancomunado de los feligreses.

\footnotetext{
González, 1985: 17-18.

4 Esta categoría abarca desde los objetos de oro y plata, así como las piedras preciosas que adornaban los ornamentos, imágenes y esculturas utilizadas para el ceremonial litúrgico, para la decoración de altares y recintos sagrados o para acrecentar la devoción religiosa. Estos elementos tenían en común el valor no solo espiritual sino también material. La lista era muy extensa pues incluyó cálices, copones, campanas, incensarios, cucharas, bandejas, cruces, candelabros, coronas, rosarios, sagrarios y custodias, entre otros más.

Pacheco, 1955: 170 .

Instituto de Cooperación Iberoamericana (ICI), 1986: 8-11.

Fajardo, 2009: 25-26.
} 
Desde 1808, España entró en una etapa de crisis tras la abdicación y prisión del Rey Fernando VII y la invasión napoleónica. Esto creó un vacío en el poder y marcó el inicio de un período revolucionario experimentado tanto en la sede del Imperio ${ }^{8}$ como en las colonias americanas.

Durante el proceso de Independencia de la Nueva Granada, el estamento eclesiástico se vio profundamente debilitado tanto en su condición social y económica, así como por los efectos provocados por el conflicto político y militar9 . Sus rentas mostraron una considerable disminución y bastante frecuentes fueron las incautaciones, expolios y destrucciones de edificaciones religiosas, pinturas, esculturas, retablos, alhajas, ornamentos y bibliotecas, además de la adecuación improvisada de iglesias y conventos como cuarteles.

El trabajo de orfebrería litúrgica experimentó durante esta época una ostensible disminución en la demanda. Un ejemplo palpable de ello fue el maestro platero y orfebre Joaquín Matajudíos en la ciudad de Santa Fe, quien pasó de elaborar rutinariamente ornamentos religiosos ${ }^{10}$ a fabricar arreos militares como espadas, charreteras, espuelas, hebillas, vainas de sable, insignias militares, botones de uniforme, medallas honoríficas y cartucheras, al tiempo que atendía pedidos de personalidades prestantes, tal como fue el caso de las tres tazas de plata que fabricó para el general Rafael Urdaneta o los cubiertos que elaboró para los generales Francisco de Paula Santander y Simón Bolívar ${ }^{11}$.

Por estos años, se hizo evidente también el decaimiento de la fe tras la influencia de las ideas ilustradas y revolucionarias, signos claros de un proceso paulatino de secularización. Esta nueva dinámica ideológica conllevó a un proceso de transición en el que la relación Reino-súbdito empezó a ser sustituida por el vínculo naciónciudadano $^{12}$.

Esta etapa, en la cual patriotas y españoles entablaron una larga lucha por el poder político, comprendió tres fases claramente definidas: la Primera República Federativa (1810-1815), la Reconquista española (1815-1819) y la Segunda República (18191824).

Durante esta convulsionada etapa, tanto los españoles como los republicanos procuraron ganar legitimidad recurriendo a la religión. Los primeros, usándola como instrumento de dominación al plantear que sin Rey no había fe católica y arremetiendo contra los aliados del movimiento independentista, tildándolos de pecadores e impíos. Los segundos, proclamando las naturales coincidencias entre el sistema americano y el cristianismo y, asimismo, impulsando una campaña antiespañola que pretendía menoscabar el sistema político monárquico, articulando el terror vivido durante el período de Reconquista con la destrucción y opresión impuesta por espacio de tres siglos de dominio colonial ${ }^{13}$.

8 Dentro de los muchos templos españoles profanados y esquilmados por los invasores franceses, cabe mencionar los de Burgos, Gerona, Cuenca, Rioseco y Córdoba, así como también el monasterio de las Huelgas, la iglesia de Compostela, el monasterio de la Mejorada en Valladolid y el Escorial en la ciudad de Madrid. Villanueva, 1935: 279-281.

9 Álvarez, 2010: 63.

10 Este maestro elaboró a finales del periodo colonial custodias, cálices y ciriales para las iglesias de Santa Fe, Mariquita, Tena, Tensa, Bosa y Choachí, entre otras.

11 Rodríguez Maldonado, 1945: 10-11.

12 Borja, 2012: 144.

13 Rey-Márquez, 2010: 9-15. 
Los actos litúrgicos llevados a cabo durante estos años, entrañaban un gran trasfondo político en el propósito por afianzar las adhesiones en torno al proyecto político en marcha. Con frecuencia, los ejércitos y las batallas se encomendaban a algún santo patrono o a otra figura católica como fórmula de protección divina. Fue además muy común la presencia y el uso de elementos sagrados del ceremonial católico para refrendar los sentimientos de fidelidad política, como por ejemplo en la procesión con imágenes sagradas ${ }^{14}$ y en la exposición del Santo Sacramento, entre otros rituales.

Sin duda, durante este proceso independentista el estamento eclesiástico pudo demostrar los verdaderos alcances de su capacidad de influencia en la esfera de lo político. Bien es sabido que, tanto el clero secular como el regular, asumieron un papel muy activo durante la polarización política vivida en estos años.

Desde luego, este ambiente de tensión y sectarismos permeó como nunca antes el estamento eclesiástico, registrándose en su interior fuertes divisiones políticas e ideológicas. Aunque se presentaron ciertas tendencias regionales, como fue el caso de la adhesión de la Iglesia en la provincia de Pasto a favor de las banderas del Rey, en términos generales no se puede hablar de una posición homogénea sino que es necesario establecer matices a nivel local e incluso considerar la existencia de divergencias de criterio al interior de un convento o entre una parroquia u otra.

Muchos religiosos fueron perseguidos por sus inclinaciones políticas mientras que las instalaciones y propiedades de los conventos e iglesias padecieron graves perjuicios por cuenta del intenso conflicto político y militar. Dentro de estas pertenencias, sin lugar a dudas las alhajas y los ornamentos fueron los más apetecidos por la facilidad para cargarlos y comercializarlos en razón a su apreciable valor por contener oro, plata y piedras preciosas.

En el marco de la celebración del Bicentenario de la Independencia de las naciones hispanoamericanas, este artículo tiene por objeto analizar el saqueo, la ocultación, la transformación y la destrucción de las alhajas de iglesias y conventos en el marco del conflicto político y militar de la emancipación neogranadina en el territorio que actualmente corresponde a la República de Colombia. Así entonces, durante estos agitados años las alhajas estuvieron inmersas en un ambiente signado por la polarización política, el afán de conseguir recursos para la guerra y la devoción religiosa.

Este trabajo se inscribe dentro de la corriente historiográfica político religiosa, la cual reconoce el importante papel asumido por la institución eclesiástica pero inmersa en procesos históricos más amplios y complejos que implican una continua interrelación con actores sociales y políticos ${ }^{15}$. La investigación se realizó con base en fuentes documentales de archivo, periódicos de la época, informes oficiales, crónicas, compilaciones normativas, cartas y fuentes secundarias.

14 A principios del mes de mayo de 1816, en los estertores del primer gobierno republicano, el comandante francés Manuel de Serviez había traído la imagen de la Virgen de Chiquinquirá, la más venerada en todo el territorio neogranadino desde tiempos coloniales' y la paseó por varios pueblos del altiplano circundante a Santa Fe en el desesperado intento por alentar a los habitantes a defender la Patria en momentos en que las huestes de Reconquista invadían sin mucha resistencia el territorio. Rodríguez Villa, 1910: 221.

15 Cortés, 2010: 181-186. 


\section{Robos y saqueos en medio de la campaña militar}

Durante el fragor de las campañas y de los combates desarrollados en el proceso de Independencia, las alhajas sagradas fueron sin duda uno de los elementos más vulnerables. Los militares y las autoridades políticas y religiosas se batieron en un juego de fuerzas por mantener el dominio sobre estas piezas sagradas en un ambiente marcado por el odio y la venganza.

Como bien se sabe, en las guerras de Independencia fue una costumbre que los ejércitos estuvieran acompañados de capellanes que se encargaban de los improvisados oficios religiosos y de brindar atención espiritual a los combatientes y a los caídos en el campo de batalla. Para el bando republicano, quizás el caso más representativo fue el Padre fray Francisco Antonio Florido mientras que en las tropas españolas de Reconquista lo fue el Padre Luis Villabrille. Al calor del combate, las reducidas alhajas y ornamentos llevados en campaña quedaban expuestos y por lo general eran presa del bando victorioso.

El 16 de abril de 1816 el coronel del Ejército de Reconquista, Francisco Warleta, venció de manera contundente en La Ceja, provincia de Antioquia, a las tropas republicanas al mando del oficial Andrés José Linares. En su retirada, los republicanos dejaron municiones, mulas, reses, pailas de rancho, víveres y hasta los vasos sagrados y ornamentos con los que su capellán les oficiaba misa ${ }^{16}$.

Aparte de estas alhajas llevadas en campaña, la mirada de los ejércitos en contienda se centró en los elementos sagrados que atesoraban las iglesias y los conventos de los poblados. Estas fueron las alhajas recogidas por el teniente coronel español Carlos Tolrá en la victoria obtenida en la batalla de La Plata a mediados de 1816: un cáliz de plata, una custodia de viril de plata sobredorada, dos cruces de plata de estandarte, una cruz de plata de Santo Domingo, una patena de plata, una cruz de altar chiquita de plata, una naveta de incienso, dos cucharas de vinajera, un platillo con dos vinajeras, una corona de la Virgen, otra corona de mayor tamaño, un guarda hostias de plata, una ampolleta de santos óleos y una media luna de la Virgen. Estos elementos sagrados fueron dejados en depósito en poder de un cura de apellido León hasta que se esclareciera a qué iglesia pertenecían ${ }^{17}$.

El Brigadier de los Reales Ejércitos don Miguel de la Torre, mediante carta fechada el 10 de julio de ese mismo año, dio aviso de haber ocupado la ciudad de Pore en los Llanos Orientales sin resistencia alguna de los rebeldes pero sí causando en ellos una gran dispersión. Al llegar, dentro de los muchos destrozos observados en el pueblo estaba el robo de una custodia y unos vasos sagrados que se encontraron en una casa particular arrojados por el suelo. Al ver esta "profanación”, Torres ordenó destinar inmediatamente estas piezas al culto divino, quedando entre tanto en su poder hasta que pudiesen estar bajo el cuidado de personas de confianza ${ }^{18}$.

Varios vasos sagrados y alhajas de iglesia fueron decomisados por el teniente coronel José Carvajal a las huestes realistas en la acción del 23 de septiembre de 1820 en la población de Barbacoas, en la costa Pacífica. Esta fue la relación de los elementos decomisados: una custodia de plata, un cáliz con su patena, un par de vinajeras con su platillo, incensario e isopo, una concha de bautizar, un resplandor,

Boletín del Exército Expedicionario, no 27, 17-VII-1816, 1.

Gazeta de Santafé de Bogotá, capital del Nuevo Reino de Granada, n. 8, 1-VIII-1816, 67-68.

Boletín del Exército Expedicionario, n 34, 27-VII-1816, 4. 
una coronita imperial, cuatro cruces de diversos tamaños de plata, un mantel y cortinas del sagrario. Por instrucciones del gobernador y comandante general de la provincia, estas alhajas fueron entregadas al cura de Nare para hacerse cargo de ellas. En la Gazeta de Santafé de Bogotá se criticó el irrespeto de los enemigos a estos artículos sagrados y el buen tratamiento que solían brindar los patriotas ${ }^{19}$.

Fueron muy comunes también los rumores que tenían como propósito enfatizar en las crueldades del enemigo. Esto fue lo que el cronista José María Caballero escuchó en Santa Fe a finales de 1814 respecto a las supuestas actuaciones del oficial patriota Simón Bolívar al frente de las tropas federalistas: "[...] venía saqueando los pueblos, estropeando a los sacerdotes, como que decían que habían colgado de las manos al cura de Chocontá, porque no le daba dinero, y lo mismo había hecho con otros tantos, robando las alhajas de las iglesias, y varias crueldades y atrocidades. Ello puede ser, pero yo no lo creo; si fuera español creería eso y mucho más; pero americano, lo dudo" 20 .

Se registró también el accionar de algunos funcionarios, militares y religiosos que aprovecharon la situación de caos para asaltar de manera deliberada los templos en busca de oro, plata y piedras preciosas para disponer de ellas a su antojo y sin dar el debido reporte a sus superiores. Fuertes censuras y sanciones se aplicaron sobre los causantes de estos excesos.

Antonio Martínez, uno de los militares al servicio del oficial patriota Manuel de Serviez, robó en mayo de 1816 algunas de las alhajas que adornaban la imagen de la Virgen de Chiquinquirá. Martínez fue juzgado por un tribunal militar y en su defensa confesó que había tomado estos elementos de valor porque supuestamente la Virgen se los había entregado para socorrer a su familia y a sus hijos ${ }^{21}$.

A principios del mes siguiente, se informó sobre la conducta reprochable de don Luis Villabrille, capellán mayor del Ejército Pacificador. Según denuncias presentadas por el arzobispo de Santa Fe, don Juan Bautista Sacristán, el cuestionado capellán en unión con algunos militares se habían apoderado de vasos sagrados, alhajas de valor, dinero y otros elementos decomisados a algunas iglesias de pueblos desafectos y a los eclesiásticos sumariados por la Vicaría castrense. El total del robo se estimaba en varios miles de pesos.

Como consecuencia de esta queja, el comandante del Ejército de Reconquista don Pablo Morillo ordenó de inmediato el arresto de Villabrille, así como de los otros implicados: don Francisco Jaureguiberroy del Escuadrón de Artillería, don José Melgarejo del batallón Húsares de Fernando VII y don José Gracia del Regimiento de Infantería de Victoria, para lo cual se iniciaron las averiguaciones del caso que fue remitido para conocimiento de las autoridades judiciales de la ciudad de Santa Fe y del Ministro de Guerra de España. Bastante sorprendido se mostró Morillo ante el mal comportamiento del religioso: "Este capellán ha abusado enteramente de la confianza que había merecido al Teniente Vicario General y aún de la mía, procediendo de un modo muy ajeno de su sagrado ministerio y del carácter en que estaba constituido"22.

En otra carta dirigida por Morillo al Secretario de Estado el 19 del mes de diciembre, le informó que se había abierto una sumaria contra el subteniente

\footnotetext{
Gazeta de Santafé de Bogotá, capital del Nuevo Reino de Granada, nº 63, 8-X-1820, 174.

Caballero, 1946: 174

Mesanza, 1936: 105.

Bonilla, 2011: 187.
} 
agregado al $2^{\circ}$ batallón del Rey don Juan Suárez por haber robado algunas alhajas de la Virgen patrona de Sogamoso. Por dictamen del Consejo de Guerra Permanente y, de acuerdo a la Ordenanza Militar, el acusado fue sentenciado a pena de privación de su empleo y a seis años de presidio en Santa $\mathrm{Fe}^{23}$.

Algunos particulares y bandidos aprovecharon también el caos y la confusión de la guerra para cometer ilícitos. La crítica situación económica que se vivía durante estos tiempos de guerra puede ayudar a explicar por qué algunos se atrevían a cometer estos delitos debiéndose atener a las recriminaciones y castigos, tanto de las autoridades como de la justicia divina. A mediados de 1816, se reportó en la ciudad de Santa Fe un robo en la capilla de Jesús Nazareno, recinto al cual ingresaron algunos intrusos rompiendo la pared y llevándose las mallas, los candeleros y otras cuantas alhajas. Al parecer, el ambiente de inseguridad por estos días era la constante pues se registraban continuos saqueos a las personas y a las haciendas ${ }^{24}$.

Hacia 1822 en la ciudad de Rionegro, provincia de Antioquia, fueron juzgados Manuela Martínez y su marido Camilo López por haber robado la corona de la Virgen de la Concepción ${ }^{25}$. También vale mencionar la causa criminal seguida años más tarde contra Carmen León y Carmen Alfonso por el hurto de las alhajas de la Virgen del Rosario de Belén de Cerinza, en la provincia de Tunja ${ }^{26}$.

Cuando no se tomaban las alhajas por medio de la acción militar directa, se optaba por conminar a las iglesias y conventos a entregarlas so pena de graves represalias. Otras alternativas afanosas, aplicadas por cada uno de los dos bandos para financiar la guerra, eran las contribuciones forzosas mediante las cuales se fijaba una cuota fija a cada vecino e incluso a los curas para que organizaran recolectas entre sus feligreses.

El colegio de franciscanos de la ciudad de Popayán, caracterizado por su adhesión a la bandera monárquica, se vio precisado a entregar el 11 de febrero de 1814 al capellán del ejército republicano fray Francisco Antonio Florido varias alhajas de plata de la sacristía, de acuerdo a las instrucciones que en tal sentido había impartido el general Antonio Nariño ${ }^{27}$.

Dos años más tarde, el gobierno de la Unión ordenó al convento de Santa Clara de la ciudad de Pamplona y a la iglesia del valle de las Angustias enviar todas sus alhajas para apoyar la causa republicana que se veía amenazada tras el avance impetuoso de las tropas de Reconquista. Para ello, se instó al general Antonio Baraya para que brindara seguridad a las 15 cargas que habían arribado a la ciudad de Tunja. En Zipaquirá, ante la presencia cercana de las fuerzas realistas, las autoridades locales expresaron honda preocupación por no contar con un sitio adecuado donde guardar las alhajas a su paso por esta población, pues ni siquiera la cárcel ni la casa de gobierno ofrecían las garantías suficientes. Ante esta situación, se pidió acelerar el envío hacia la localidad de Funza donde podían estar mejor protegidas ${ }^{28}$.

23 Ibídem; 186.

24 Caballero, 1946: 255.

25 Causa criminal contra Manuela Martínez y su marido Carlos López por robar la corona de la Virgen de la Concepción. Rionegro, 25-IX-1822. Archivo General de la Nación [Colombia] (en adelante AGN), Sección República, Fondo Asuntos Criminales, tomo 43, ff. 641r-667v.

26 Causa criminal contra Carmen León y Carmen Alfonso por robo de alhajas de la Virgen del Rosario de Belén de Cerinza. Sogamoso, 19-X-1826. AGN, Sección República, Fondo Asuntos Criminales, tomo 53, ff. 450r-472v.

27 Mantilla, 2000: 583-584.

28 Sobre remisión de 15 cajas que contienen las alhajas del monasterio de Santa Clara, hecha por el gobernador de Tunja. Zipaquirá, 12-IV-1816. AGN, Sección Archivo Anexo, Fondo Asuntos Eclesiásticos, tomo 26, ff. 481r- 
Las exigencias de las autoridades políticas y militares no pasaron del todo desapercibidas entre la comunidad de feligreses, quienes en ocasiones buscaron a toda costa defender las alhajas sagradas de sus templos como parte del patrimonio espiritual de cada localidad. Necesitado de recursos para emprender la campaña en el Sur, el Libertador Simón Bolívar envió en 1821 a la población de Barbacoas en la Costa Pacífica al coronel Ángel María Varela en busca de oro. El oficial reunió a los vecinos del lugar y los puso en una seria disyuntiva: reunir una cantidad suficiente de oro o de lo contrario se llevaría las alhajas de la iglesia, dentro de las cuales las más vistosas eran las que engalanaban a la Virgen de Atocha, patrona del lugar.

La custodia lucía 233 diamantes, 77 esmeraldas y 63 amatistas, y su peso era de 21 libras. El rosario de oro estaba adornado con 119 perlas, la corona de la Virgen y la corona del niño Jesús eran de oro y estaban cubiertas también con numerosas piedras preciosas. Los zarcillos de la Virgen tenían 133 chispas de diamante y 14 topacios.

La oposición de la comunidad a la segunda de las alternativas planteadas por el oficial Varela fue rotunda y, por lo tanto, en aras del sacrificio las prestantes damas y sus esposos ofrecieron sus anillos, collares, zarcillos y demás aderezos personales, cuyo peso fue superior al de las pretendidas alhajas sagradas. También se recibió la donación de los síndicos y del cura Francisco Paladines y Romero, quienes entregaron dos quintales de plata labrada en chapas laminadas en relieve sacadas del frontispicio y de las pilastras del altar mayor, además de otras cuantas coronas, diademas y rosarios. De esta manera, se salvaron las alhajas sagradas de las pretensiones de las fuerzas republicanas ${ }^{29}$.

\section{Las alhajas confiscadas}

Un antecedente claro de confiscación de alhajas de iglesias durante el periodo colonial se dio con ocasión de la expulsión de la comunidad de los jesuitas en $1767^{30}$. Algunas de esas piezas fueron destinadas para dotar otras iglesias, tal como sucedió con aquellas que pertenecían al templo de la hacienda de Caribabare que fueron luego utilizadas para la naciente parroquia de Nunchía, en los llanos Orientales ${ }^{31}$.

Todavía en el periodo de Independencia seguía recurriéndose al fondo de Temporalidades encargado de administrar los bienes de los desterrados jesuitas. El 14 de julio de 1813, por orden del presidente Antonio Nariño, se recibieron en la tesorería de la casa de la Moneda de Santa Fe varias alhajas de plata pertenecientes a dicha comunidad religiosa, con el fin de proceder a la amonedación para apaciguar los apremiantes gastos de los ejércitos republicanos ${ }^{32}$.

En el marco de la guerra, el embargo de bienes fue utilizado como instrumento de represión económica para vulnerar las potencialidades del enemigo afectando no solo a los grandes empresarios y hacendados sino también a pequeños propietarios, modestos comerciantes e incluso a los curas y a las congregaciones religiosas ${ }^{33}$.

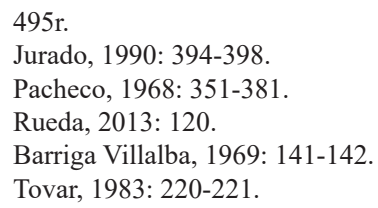


Por su valor comercial, las alhajas tanto privadas como sagradas fueron incluidas dentro del cúmulo de pertenencias secuestradas $\mathrm{y}$, por consiguiente, pasaron por varias manos, conforme al vaivén de las circunstancias y de las revanchas políticas. La dinámica misma del conflicto permite marcar una periodización de acuerdo con el bando que ostentaba momentáneamente el poder.

A partir de finales de 1815, cuando los españoles recobraron las riendas del gobierno en el vasto territorio neogranadino, las operaciones de decomiso de bienes adquirieron un auge inusitado. En 1816, el Pacificador Pablo Morillo expidió desde su cuartel general de Santa Fe un bando dirigido a cada una de las provincias, en cuyo artículo $3^{\circ}$ planteó como deber de todo vasallo del Rey denunciar y entregar los caudales, las alhajas, los esclavos y, en general, todos los bienes pertenecientes a los rebeldes y emigrados. Los contraventores de esta norma serían responsabilizados con sus personas y patrimonios ${ }^{34}$.

Lo anterior sirvió de precedente para crear a los pocos días la tan renombrada Junta de Secuestros, un órgano destinado a desarticular futuros esfuerzos económicos en favor de la gesta libertaria y a dejar en la orfandad y miseria a los "conspiradores" que atentaban contra el régimen español. Con la creación de esta institución, se pretendía formalizar y regularizar las operaciones de embargo que antes se hacían algunas veces de manera caprichosa y arbitraria, en medio del fervor revanchista vivido en la campaña militar de Reconquista. Muy pronto, se empezaron a instalar estas juntas en las principales ciudades.

En febrero de 1816, el gobernador de Cartagena don Gabriel de Torres solicitó el embargo de las alhajas del canónigo Benito José Lambi. Dentro de los elementos decomisados, se encontraba un cáliz dorado con su platillo, unas vinajeras con su campanita y una palangana grande $\mathrm{e}^{35}$.

La junta de secuestros de la ciudad de Santa Fe ordenó en el mes de junio la confiscación de los bienes, alhajas y escritos de fray Diego Padilla y demás religiosos de la Orden de San Agustín, acusados de insurgentes y de haber migrado a la llegada del ejército de Reconquista. En el proceso se hizo una indagatoria a Camilo Manrique, quien se hallaba preso para que confesara si el dicho Padre Padilla había ocultado o depositado algunas de las alhajas ${ }^{36}$.

Según el cronista José Manuel Restrepo, el oficial español Francisco Warleta remitió a finales de este mismo año al general Pablo Morillo un total de diez cajones de alhajas y ornamentos de los templos de las provincias del Sur, elementos que habían sido incautados en calidad de secuestro en inmediaciones de Popayán al presidente de la Unión don José Fernández de Madrid ${ }^{37}$. José Martín Carpintero, funcionario de la Junta de Secuestros, entregó a las Reales cajas un total de 740 pesos y seis reales procedentes de la venta de estas alhajas ${ }^{38}$.

Por esos mismos días, algunas joyas sagradas pertenecientes a varias iglesias se habían llevado por las autoridades militares españolas hasta la ciudad de La Plata.

Proclamas y bandos del general Morillo. Santa Fe, 14-VI-1816. AGN, Fondo Archivo Histórico Restrepo, rollo 14, fondo IX, vol. 4, f. 354r.

35 El gobernador de Cartagena ordena el embargo de las alhajas del canónigo Benito José Lambi. Cartagena, 18II-1816. AGN, Sección Archivo Anexo, Fondo Secuestros, tomo 2, ff. 237r-240r.

36 Orden del gobierno español para el inventario y avalúo de los bienes de don Diego Padilla. Santa Fe, 12-VI1816. AGN, Sección Archivo Anexo, Fondo Secuestros, tomo 4, ff. 551r-562v.

37 Restrepo, 2009 [1858]: 435.

38 Gazeta de Santafé de Bogotá, capital del Nuevo Reino. de Granada, nº 23, 14-XI-1816, 242. 
Allí se hizo un registro por el poco peso y se descubrió que había una buena cantidad de vestidos de iglesia ${ }^{39}$.

\section{Prevenciones, juzgamientos y omisiones}

Ante la inminente llegada de tropas enemigas, una práctica muy común durante las guerras de Independencia fue asegurar las alhajas sagradas con el fin de que no fueran raptadas o destruidas por la contraparte. Así entonces, una decisión oportuna podía salvar el patrimonio material y espiritual de las iglesias y de los conventos.

En julio de 1810, durante las primeras manifestaciones de autonomía política, el convento de capuchinos de la villa del Socorro se convirtió en sitio de refugio para las autoridades españolas que huían del ataque del pueblo enardecido. En esta ocasión, los frailes, sindicados también de simpatizar con la causa realista, fueron objeto de toda clase de insultos y desprecios, razón por la cual huyeron recogiendo en sacos "[...] los caudales, las joyas, los vasos sagrados y demás objetos valiosos del culto" 40 .

A finales de 1812, varios pueblos de las Sabanas de Tolú y del Partido del Sinú, con el auspicio de los regentistas de la ciudad de Santa Marta, juraron fidelidad al Rey Fernando VII y se alzaron en contra del gobierno republicano recién establecido en la provincia de Cartagena. Don Pedro Martín Antonio Vásquez, cura de Sampués, solicitó al año siguiente al cura de Oveja que asegurara los vasos sagrados y ornamentos ante la amenaza de que el pueblo fuera incendiado pero el religioso salió en precipitada fuga y Vásquez procedió entonces a solicitar la llave del sagrario para guardar aquellas piezas valiosas y luego entregarlas bajo el cuidado de un grupo de vecinos. Después de concluidos los combates, se supo que el sagrario estaba en la choza de un vecino a la orilla del monte y allí Vásquez lo abrió por la fuerza y recogió los vasos sagrados y otras efigies y ornamentos que finalmente quedaron en el sitio de Corozal. El cáliz, la custodia y el copón habían sido entregados al cura de Tenerife por orden del comandante en jefe don Pedro Domínguez ${ }^{41}$.

En una carta dirigida en 1814 por fray José Antonio Villa del convento de San Antonio de Padua de la ciudad de Pamplona, se informó sobre el mensaje enviado por Buenaventura Arias, gobernador de Mérida, en el cual recomendaba que, en caso de amenaza política ante la inminente llegada de las fuerzas españolas, debían esconderse en un lugar seguro los objetos de oro y plata, y los ornamentos más valiosos ${ }^{42}$.

Antes de que los republicanos evacuaran la plaza de Cartagena en 1815, tras el sitio impuesto por el comandante español Pablo Morillo, el gobierno local impartió órdenes al ciudadano Jorge López para que recogiera todas las alhajas de oro y piedras preciosas de las iglesias de la ciudad, entre ellas la gran custodia de la catedral ${ }^{43}$.

\footnotetext{
39 Gazeta de Santafé de Bogotá, capital del Nuevo Reino de Granada, no 22, 7-XI-1816, 231.

40 Rodríguez Plata, 1963: 34.

41 Martínez - Gutiérrez, 2010: 183-184.

42 Mensaje enviado por el gobernador de Mérida para proteger los ornamentos del convento de San Antonio de Padua. Pamplona, 21-VI-1814. Archivo de la Provincia de San Luis Beltrán de Colombia, Convento de San Antonio de Padua de Pamplona [Colombia], serie correspondencia, caja 1, carpeta 3, expediente 6, ff. 1r-8v.

43 El convento hospital San Juan de Dios de Cartagena por las alhajas que se tomaron. Cartagena, 21-XI-1815. Biblioteca Luis Ángel Arango en Bogotá [Colombia] (en adelante BLAA), Sala de Libros Raros y Manuscritos, Documento $n^{\circ} 93$, f. 2.
} 
A principios de 1816, cuando las tropas de Reconquista avanzaban impetuosas acercándose a la provincia de Tunja, los Padres dominicos de Chiquinquirá decidieron recoger todas las alhajas de la iglesia de la Virgen y emigraron hacia Santa Fe. En el mes de abril estas piezas sagradas estaban en Chocontá bajo el control de las tropas al mando del oficial Manuel de Serviez ${ }^{44}$.

También por esos días, el provincial de Predicadores pidió la aprobación del gobierno de la Unión para que los ganados y las alhajas del convento de Santo Eccehomo en la provincia de Tunja fueran retirados ante la inminente llegada del gran ejército de Reconquista. En efecto, las tropas españolas llegaron a este territorio el 30 de abril de 1816 y ocuparon el monasterio. La comunidad religiosa tenía sobradas razones para temer una eventual represalia pues, en los dos años anteriores, habían colaborado al gobierno republicano con dos donativos de 200 pesos cada uno ${ }^{45}$.

Al parecer, el triunfo de los patriotas en la crucial batalla del campo de Boyacá el 7 de agosto de 1819 tomó por sorpresa al gobierno virreinal asentado en Santa Fe que confiaba ciegamente en sus militares ${ }^{46}$. También resultaron sorprendidos los integrantes de la comunidad de los franciscanos, quienes el 8 de agosto se enteraron del triunfo obtenido por los patriotas. La desazón y la confusión invadió de manera especial a los frailes realistas que se hallaban en dicho convento y por la noche de aprestaron a preparar la huida. La prisa no les impidió que se llevaran al día siguiente algunas alhajas sagradas que estaban bajo su cuidado, todo con el argumento de que podían peligrar "en manos de los insurgentes". Así entonces, uno de ellos, fray Benito Fernández, confesó a través de una carta escrita en Santa Marta antes de disponerse a viajar a Jamaica que, por orden del provincial fray Antonio González, había recogido las alhajas para conducirlas en su viaje a aquella isla del Caribe donde permaneció como vicario apostólico hasta el año de 1843 cuando falleció aunque no quedaron pistas del paradero final de aquellas joyas sagradas ${ }^{47}$.

Cuando el líder realista Agustín Agualongo incendió la población de Barbacoas en la mañana del $1^{\circ}$ de julio de 1824 , una de las primeras edificaciones destruidas fue la iglesia que estaba construida en madera y cubierta de hojas de palma. Minutos antes, el comandante republicano Tomás Cipriano de Mosquera tuvo la previsión de impartir instrucciones a un lugarteniente suyo para que sacara la custodia y el copón con el fin de resguardarlos en el cuartel ${ }^{48}$.

En las sumarias levantadas en 1817 por las autoridades de Reconquista a varios religiosos, se pueden observar las acusaciones por el apoyo a la causa patriota y los excesos en torno al manejo y cuidado de las alhajas de iglesia. Al cura Francisco Javier Uribe se le acusó de entregar, sin el respectivo aval de la feligresía, al comandante patriota Manuel de Serviez las alhajas sagradas de la iglesia parroquial de Cerinza de donde era cura. Según las penas canónicas dispuestas por Paulo Segundo en la Constitución Ambitiosi Cupiditati, y lo fijado por el Concilio de Trento en su capítulo 11, sección 22, los curas implicados en este tipo de hechos debían ser objeto de excomunión mayor. En su defensa, Uribe alegó que había entregado las alhajas no por voluntad propia sino porque había sido conminado dos veces por el "protestante"

\footnotetext{
Caballero, 1946: 213 y 225 .

Ariza, 1966: 120.

Groot, 1891: 460.

Mantilla, 2000: 611-612.

Jurado, 1990: 406
} 
comandante Serviez a que las entregara para la causa patriota ${ }^{49}$.

A Antonio García, cura de Tunja, se le sindicó de extraer las alhajas de varias iglesias de la provincia. Un nuevo proceso se levantó contra el cura Vicente Medina de la Villa del Rosario de Cúcuta, quien huyó a la llegada del oficial español Ramón Correa, llevándose consigo las joyas sagradas del templo. Por esta falta y por otras muestras de desapego a la causa monárquica, las autoridades españolas decidieron confinar al destierro a estos religiosos, decomisándoles sus bienes y suspendiéndolos de sus curatos ${ }^{50}$.

El cura de Pore don Jorge de Mendoza reconoció haber huido tan pronto se enteró de la inminente llegada de las tropas de Reconquista. Ante esta situación, procedió a extraer las alhajas de su iglesia: una copa de perlas y oro, cinco gargantillas de cuentas de oro y perlas, y además la efigie de Nuestra Señora de la Concepción "toda de oro". No obstante, Mendoza aclaró que lo hizo con pleno consentimiento del mayordomo de fábrica de la iglesia, de los alcaldes y de los vecinos por hallarse el templo arruinado, sin puertas y sin ninguna seguridad. Según adujo, su propósito no era otro que resguardar estas alhajas del saqueo perpetrado por las huestes españolas pues, según los rumores, venían cometiendo toda suerte de excesos ${ }^{51}$.

La omisión o indiferencia ante estos saqueos también fue objeto de señalamiento. Al gobernador del arzobispado don José Domingo Duquesne, las autoridades de Reconquista le formularon serias acusaciones por no haber denunciado oportunamente los saqueos de los "insurgentes", siendo él la máxima autoridad eclesiástica de estos territorios $^{52}$.

\section{Las contribuciones voluntarias}

El otro mecanismo a través del cual se tomaron las alhajas divinas fue por cuenta de las contribuciones voluntarias que establecían los gobiernos de turno o por los ofrecimientos que de manera espontánea realizaban los curas y las comunidades religiosas como fórmula de apoyo al proyecto político de sus simpatías. Obviamente con estas donaciones, las iglesias y conventos buscaban de algún modo ganar la complacencia del gobierno de turno y a la vez obtener su protección. El problema con estas donaciones fueron las represalias que emprendían los enemigos tan pronto se enteraban de estos gestos de apoyo.

En marzo de 1814, el convento dominicano de la ciudad de Popayán auxilió al ejército republicano comandado por el general Antonio Nariño, para lo cual entregó buena parte de las alhajas de la iglesia, valoradas en 11.400 pesos $^{53}$.

A principios del año siguiente, el gobierno de la Unión le confió al líder político José Acevedo y Gómez la delicada tarea de persuadir a las comunidades religiosas para que contribuyeran a la causa revolucionaria que se veía amenazada ante la llegada del ejército de Reconquista. En respuesta a esta convocatoria, los religiosos de Santo Domingo de la villa de Chiquinquirá pusieron a disposición del gobierno republicano todas las alhajas y tesoros de su santuario. Así entonces, el 20 de enero

\footnotetext{
Hernández, 1962: 353-354.

Ibídem: 349-357.

Ibídem: 407-408.

Ibídem: 347.

Ariza, 1992: 1246.
} 
el prior fray Miguel Garnica oficializó el envío de 1.233 pesos en efectivo y un conjunto de alhajas que estaban en depósito "[...] para ocurrir con la mayor presteza a las urgencias del Estado". En su mayor parte eran alhajas de oro con incrustaciones y adornos de diamantes, esmeraldas y perlas: un collar, una cruz, seis sortijas, tres anillos, tres rosarios y un medallón de San Ignacio ${ }^{54}$.

La comunidad religiosa animada por sus "vivos sentimientos de patriotismo" no solo ofreció estas alhajas sino también las que adornaban la imagen de la Virgen:

Nuestra Señora del Rosario de Chiquinquirá está pronta a desnudarse de las alhajas que adornan su venerable imagen, siempre que el Gobierno General destine su producto para sostener la Independencia de la Nueva Granada y la libertad de sus pueblos, a cuya piedad de esos adornos, y son los siguientes: el fajón de brillantes y esmeraldas que remitió a Nuestra Señora la Duquesa de Alba, de valor de $\$ 25.000$ pesos. El resto de brillantes, rubíes, jacintos, esmeraldas, perlas y demás alhajas de oro que adornan el cuadro de Nuestra Señora, y no se enumeran por evitar prolijidad, valen, por lo menos, según el cálculo de algunos inteligentes, $\$ 70.000^{55}$.

Por este gesto, Acevedo y Gómez ratificó a la comunidad franciscana como la más decidida por la causa de la libertad, colocándola como ejemplo de sacrificio y adhesión al sentimiento patrio. A fin de cuentas, se oficializó el listado de las alhajas incluidas en el cuadro pero no se entregaron las que adornaban la Virgen.

A la llegada de las tropas de Reconquista, en abril de 1816, buena parte de los religiosos dominicos simpatizantes con la bandera republicana salieron en precipitada fuga mientras que otros reafirmaron su fidelidad a la monarquía y decidieron quedarse en el convento. No demoró mucho tiempo en que las autoridades españolas censuraran la generosa entrega de alhajas. Sin embargo, el Prior de la Comunidad no dudó en defender a sus compañeros implicados bajo el argumento de que lo habían hecho intimidados por las tropas que acompañaban al comisionado republicano Acevedo y Gómez. Gracias a estas intercesiones y al oportuno apoyo del provisor y vicario Francisco Javier Guerra, los sindicados fueron absueltos por la Real Audiencia tras ser incluidos en la lista de favorecidos por el indulto dictado el $2^{\circ}$ de enero de 1817 por el Rey Fernando VII ${ }^{56}$.

Cabe precisar que no siempre fue convocado el estamento eclesiástico en las contribuciones y convocatorias de apoyo económico por la causa política. En el decreto promulgado en Santa Fe el 9 de septiembre de 1815 por el Congreso de las Provincias Unidas, se fijó una contribución extraordinaria para paliar el déficit fiscal y para auxiliar a las tropas que defendían la República. En el artículo $7^{\circ}$ se dispuso que no serían incluidas las alhajas de las iglesias "ni ninguno de los muebles de su adorno y servicio, lo mismo los de las capillas u oratorios, rurales o urbanos" ${ }^{57}$.

\footnotetext{
Ibídem: 994-996.

Ibídem: 996.

Ibídem: 1004-1005.

Congreso, 1988: 205.
} 


\section{El destino de las alhajas}

Distintos fueron los destinos de las alhajas robadas e incautadas. En razón a la situación de escasez y estancamiento económico por cuenta de la guerra, algunas fueron amonedadas en tanto que otras fueron subastadas al mejor postor con el fin de disponer de recursos frescos para afrontar los incesantes gastos militares.

Por decreto del 17 de diciembre de 1809 en España se había dispuesto que, todas las alhajas de las iglesias que no fueran absolutamente necesarias para el culto divino, se recogieran y remitieran debidamente inventariadas a sus respectivas diócesis y de estas serían enviadas a Sevilla con el fin "justo y religioso" de protegerlas de las "atrocidades sacrílegas" de las tropas francesas y también con el propósito de que su valor sirviera para los gastos del Estado, para lo cual serían enviadas a la casa de la moneda. La medida se extendía también a las cofradías, hermandades y comunidades religiosas. Una vez cesaran las circunstancias de la guerra, serían restituidos sus valores a través de la Tesorería. Sin embargo, la Junta Suprema reportó muy pocos resultados de esta medida, siendo las iglesias de la provincia de Cuenca las que más habían contribuido.

Como sustento histórico, se recordó a San Ambrosio quien consideraba que las alhajas sagradas debían conservarse para el culto del Rey y más en casos de necesidad pública y falta de recursos: "Será pues mejor en las actuales circunstancias que el oro y la plata de nuestras iglesias, en vez de emplearse en sostener nuestra milicia cristiana, sea sacrílego despojo de nuestros bárbaros enemigos?" 58 . Se recordó además cómo los Reyes Católicos en 1475 habían avalado esta idea, comprometiéndose a restituir a las iglesias estos elementos sagrados ${ }^{59}$.

En las luchas de Independencia registradas en territorio americano, se vivió también el afán de conseguir recursos para financiar a cada uno de los dos bandos en combate. En la ciudad de Santa Fe se recibieron en febrero de 1817 dos cajas de alhajas de oro y plata provenientes de varias iglesias de la provincia de Popayán. El juez de Almonedas don José Martín Carpintero procedió a realizar el avalúo, para lo cual llamó al maestro mayor de platería don Joaquín Matajudíos. El valor total de estas alhajas fue estimado en 542 pesos y la pieza más elaborada era una custodia de filigrana de plata dorada con cuatro campanitas, avaluada en 262 pesos. Una vez cumplida esta diligencia, el gobierno virreinal dispuso lo siguiente: "[...] y las que se comprenda que pueden valer más que la materia se vendan en público remate adjudicándose siempre que resulte mayor valor [...] y las demás que desde luego se comprenda que no pueden tenerse, se pasen a la casa de moneda para que se acuñen"60.

En algunas circunstancias, las alhajas fueron salvadas de la destrucción y de la profanación, destinándolas para el propósito por el cual habían sido elaboradas, es decir, para el culto divino.

58 Real resolución e instrucción sobre la aplicación a gastos del Estado de las alhajas de la iglesia. Madrid, 17-XII1809. Biblioteca Nacional de Colombia [Colombia] (en adelante, BNC), Fondo Manuscritos, tomo 354, f. 731v.

59 Sobre el saqueo de alhajas sagradas durante el proceso de independencia en España, véase: Miguéliz, 2012: 731-759.

60 El subinspector de Cartagena da parte de haber encontrado entre las municiones llegadas a Santa Fe dos cajones de alhajas de oro y plata. Santa Fe, 23-II-1817. AGN, Sección Archivo Anexo, Fondo Guerra y Marina, tomo 148 , f. $820 v$. 
El general Pablo Morillo, la cabeza visible del gran Ejército de Reconquista, decidió a finales de 1816 brindar atención a las iglesias pobres, principalmente a aquellas ubicadas en los caminos que se estaban construyendo bajo sus órdenes. El objetivo de esta medida era asegurar por lo menos el "decente culto al Señor".

En desarrollo de este mandato, este fue el listado de los paramentos y alhajas enviadas el 22 de octubre por el provisor del arzobispado don Antonio de León para el pueblo de San Vicente de Chucurí, localizado en la región del Carare: seis casullas, capas, estolas, cuatro albas con sus amitos y seis cíngulos, un misal, una custodia de plata, un copón con tapa de plata y cubierta de brocatillo, una bolsita para relicario con beático, un cáliz, una patena, una cucharita de plata y un purificador. A estos elementos se sumaron unas vinajeras con platillo y campanilla de plata que fueron donadas por el gobernador del Arzobispado ${ }^{61}$. Estos ornamentos sacados de la casa de depósitos de secuestros fueron entregados al cura de esta naciente población, don Blas de los Reyes.

Morillo envió también a la iglesia de Motavita, cercana a la ciudad de Tunja, cinco ornamentos de distintos colores, dos albas con sus amitos y dos sobrepellices, dos cíngulos y dos palias. En noviembre de 1819, el cura de la parroquia de Quebrada Negra pidió al gobierno republicano una capa de oro y algunos de los ornamentos y alhajas que se hallaban en el depósito de secuestros ${ }^{62}$.

El escaso dinero circulante durante estos años de Independencia ${ }^{63}$ fue sin duda un gran problema a la hora de financiar los gastos de la guerra y mantener activa la economía. Para ello, en reiteradas ocasiones se recurrió a la amonedación.

En sus crónicas, José María Caballero expresó sus reservas sobre el impacto que podía generar este tipo de decisiones. Esto fue lo que anotó en julio de 1813, en momentos en que se escuchaban en Santa Fe las noticias sobre la falta generalizada de recursos y los avances militares del comandante español Juan Sámano por los lados del Sur: "[...] que metan mano en lo sagrado al culto divino y verán dónde va a parar todo" 64 .

En una carta interceptada en cercanías a la ciudad de Cartagena en septiembre de 1815 por el Ejército de Reconquista, se supo cómo el líder "insurgente" Manuel del Castillo informaba de manera angustiosa al gobierno central de Santa Fe sobre los pírricos resultados que había arrojado la medida de reducir a moneda provincial todas las alhajas de las iglesias. Por consiguiente, muy poco se había contribuido a socorrer la división del Magdalena y la guarnición republicana apostadas en esta plaza. Adicionalmente se había ordenado a todos los vecinos la entrega del oro y plata que tuvieren en sus patrimonios personales pero de esos recursos solo quedaban a la fecha 1.500 pesos en las cajas militares. Castillo pidió entonces a los gobernantes de Santa Fe el envío inmediato de apoyo para enfrentar el gran cerco militar impuesto por el Ejército Pacificador ${ }^{65}$.

En marzo de 1816, cuando las tropas de Reconquista al mando del oficial español don Sebastián de la Calzada habían logrado avanzar exitosamente hacia el interior,

Gazeta de Santafé de Bogotá, capital del Nuevo Reino de Granada, nº 25, 28-XI-1816, 257-258.

62 El cura de Quebrada Negra sobre que se le de una capa de coro y ornamentos que se hallan en el depósito de secuestros. Quebrada Negra, 15-XI-1819. AGN, Sección Archivo Anexo I, Fondo Asuntos Eclesiásticos, tomo 32, f. 531r.

63 Barriga del Diestro, 2010: 407.

64 Caballero, 1946: 140.

65 Boletín del Exército Expedicionario, n ${ }^{\circ}$ 2, 15-X-1815, 1. 
el gobierno central republicano seguía haciendo ingentes y desesperados esfuerzos por conseguir recursos. Se propuso recaudar 100.000 pesos, así fuera de las alhajas de las iglesias, pero aún no se había podido juntar nada pues fue imposible en ese momento conseguir un hombre con el liderazgo suficiente para llevar a feliz término estos propósitos ${ }^{66}$.

En otras circunstancias, las alhajas fueron fundidas para transformarse en otros elementos con un uso distinto al culto religioso. Para el estamento eclesiástico y para los feligreses, esto no era más que un acto desafiante de profanación y más cuando se utilizaba el material para elaborar toda suerte de excentricidades.

Aquí se vio no solo la destrucción y el despojo violento sino también la transformación para la elaboración de material bélico. Según el reporte presentado por el general republicano Antonio Nariño al haber recuperado la ciudad de Popayán en 1813, después del triunfo obtenido en la batalla de Calibío, fueron encontrados frontales y lienzos de santos sirviendo de sudaderos mientras que el prelado de San Agustín informó haber decomisado una escopeta a uno de los sacerdotes del comandante español Juan Sámano. Esta arma tenía como adornos dos pedazos de patenas y de vasos $\operatorname{sagrados}^{67}$.

Ese mismo año, luego de la prisión de Nariño y de las amenazas del gobernante español don Toribio Montes, los republicanos asentados en esta ciudad lanzaron a través del periódico La Aurora la siguiente denuncia sobre los desmanes del enemigo:

No están acostumbrados estos pueblos a ver insultada la religión en sus misas, en sus templos y en sus vasos sagrados, no quieren que se repitan las escenas de abofetear a los sacerdotes, y de imponerles bayonetas a los pechos; de saquear los templos y de excavar los sepulcros. Tampoco pueden escandalizarse que se beba aguardiente en los copones, que oculten las mujeres llamadas voluntarias la patena en sus senos y los cálices en las mochilas: que se conviertan las albas en camisas, las casullas en calzones, y que las pinturas de los santos sirvan de sudaderos en las caballerías ${ }^{68}$.

Ya se mencionó en líneas anteriores a Luis Villabrille, vicario general del comandante Morillo, quien fue acusado de causar escándalo con el pillaje que hizo de las alhajas de las iglesias de algunos pueblos, además de la fuerte represión emprendida contra algunos sacerdotes simpatizantes con la causa republicana. Villabrille mandó hacer a los plateros no solo cubiertos de plata con aquellas alhajas sino también estribos y espuelas ${ }^{69}$.

En 1817 don Silvestre Figueroa, cura de la parroquia del Palmar, en la provincia del Socorro, denunció cómo las tropas del coronel español Sebastián de la Calzada no se contentaron con saquear las alhajas sino que además habían elaborado espuelas con los vasos sagrados ${ }^{70}$.

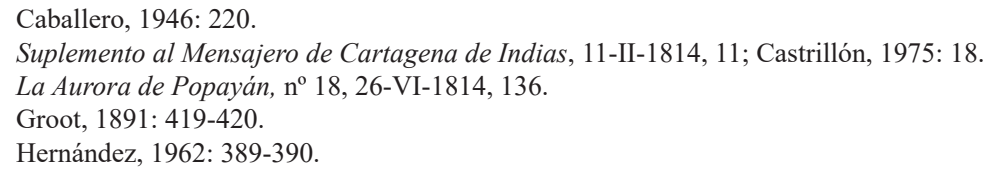




\section{La lucha por la recuperación de las alhajas}

Numerosos litigios relacionados con reclamos de restitución de alhajas saqueadas y decomisadas resultaron prolongándose en el tiempo a causa de los súbitos cambios de gobierno y las variaciones en la normatividad vigente. Las fluctuantes estructuras administrativas y la continua salida de funcionarios eran muy poca garantía para lograr respuestas oportunas. Así por ejemplo, varios afectados esperaron a que sus aliados políticos volvieran al poder para elevar con más sustento y esperanza sus reclamos.

Las iglesias y conventos afectados, así como sus feligresías, sentían con profundo desazón el desamparo espiritual a raíz de la pérdida de sus ornamentos y alhajas y, en respuesta a ello, emprendieron campañas y estrategias para recuperarlas. Este era sin duda un camino expedito, dada la dificultad económica que había en estos tiempos de guerra para adquirir nuevas piezas. Cuando se trataba de piezas especialmente elaboradas y que gozaban del aprecio y la devoción popular, se intentó por todos los medios recuperarlas pero, en otros casos, se buscó la compensación con otras piezas de la misma clase o una tercera opción que fue el resarcimiento en dinero, según el valor de las piezas comprometidas.

El Ejército Expedicionario de Reconquista reafirmó su derecho sobre los elementos incautados al enemigo. Particularmente sobre los vasos sagrados y ornamentos de las iglesias que se encontraran en manos de los "rebeldes" en los campos de batalla y en otros puntos, dispuso el general Pablo Morillo que, "por ley general [y] bajo graves cargos", debían entregar estos elementos sagrados a los curas a quienes correspondían ${ }^{71}$. No obstante, esta medida no se cumplió a cabalidad.

Don Sebastián Meléndez, cura de Sátiva, presentó el $1^{\circ}$ de noviembre de 1816 una carta al prebendado don Nicolás Cuervo, en la cual reclamaba las alhajas que le habían sido saqueadas por orden del comandante "insurgente" Manuel de Serviez. Meléndez adjuntó el listado detallado de estos ornamentos que habían sido introducidos en dos baúles cubiertos de cuero para ser luego enviados a Santa Fe.

Con el ánimo de seguir el rastro de estos elementos incautados, se elevó una petición al tribunal de secuestros para que efectuara la respectiva revisión en sus depósitos. El juez de almoneda don Carlos Manuel Ledesma aclaró que en días anteriores se había enviado a la parroquia de Cerinza una custodia de plata y un incensario pero en los depósitos no reconoció ninguna otra pieza de plata como las que se reclamaban. También habían llegado dos cajones que, en calidad de pertrechos fueron entregados por el batallón de Artillería, en donde venían 16 candelabros de cobre, 11 de hierro y 11 campanitas de cobre. Ante esta incertidumbre, la Junta recomendó al cura lo siguiente:

Como no se dan unas señas individuales capaces para servir de norte, sin riesgo de equivocaciones para el cotejo con lo vendido y existente de lo que contenían 29 y medio cargas de ellas que se depositaron, no es fácil acertar; y por lo mismo el depositario que informa cree, ser indispensable que por el cura solicitante se nombre dos o tres sujetos de integridad y de conocimientos de los bienes de su iglesia, a quienes poniéndoseles de manifiesto las alhajas y ropas existentes [se pueda determinar] si están o no las que se reclaman y poderse asegurar el acierto ${ }^{72}$.

Bonilla, 2011: 87.

72 El cura de Sátiva reclama las alhajas saqueadas por orden del comandante Manuel de Serviez. Sátiva, 12-XI- 
En respuesta a esta sugerencia, Meléndez comisionó a don Juan Crisóstomo Gómez con el fin de levantar un inventario más minucioso y descriptivo. Entre este listado, la pieza más valiosa era una custodia “[...] sobredorada con sus estrellas en los rayos, serafines postizos en el pie remachados por lo invisible, y toda ella con muchas filigranas en sus piezas, tiene su guijo pendiente de una cadenita". A fin de cuentas, al verificarse el respectivo cotejo con los depósitos, no se halló ni esta ni ninguna otra de las alhajas perdidas.

El general republicano Antonio Nariño había decomisado a la iglesia del pueblo de $\mathrm{Suba}^{73}$ un palio, un guión, una salvilla con su vinajera y campanilla, una media luna y un vaso de purificación. En agosto de 1816, pocos días después de haber recuperado los españoles el poder central, el cura de aquella población don José Antonio Ochoa supo que estos elementos sagrados se iban a fundir en la casa de la Moneda y procedió a pagar por ellos 456 pesos, pues los consideraba indispensables para el culto divino. El hecho fue denunciado ante las autoridades españolas que pocos días atrás habían recibido una queja similar por parte del prior de La Candelaria. El general Pablo Morillo intervino en esta situación y dio orden de devolver las alhajas a sus lugares de origen ${ }^{74}$.

Amediados de junio de 1818, el convento de Santa Clara de la ciudad de Pamplona a través de la abadesa María de Jesús, solicitó al virrey Juan Sámano la restitución de las alhajas remitidas a Santa Fe por orden del gobierno republicano. La religiosa relató cómo en 1813 se habían visto obligadas a enviarlas a la cercana parroquia del Cerrito para protegerlas del ataque de las fuerzas republicanas, enterándose tres años después de la orden impartida por el gobierno central para entregarlas al servicio de la causa republicana. Estos fueron los términos de la angustiosa carta en la que la comunidad religiosa hacía ver la necesidad que tenía de recuperar estos elementos sagrados:

Este Monasterio que se halla en tanta indigencia y miseria hace algunos años, al ver su templo desnudo de sus paramentos y las imágenes de sus vestiduras, el sagrario y altares y vasos sagrados, que aún para una u otra festividad que no puede omitirse, se halla en la necesidad de prestar de otras iglesias con qué celebrar, al verse tan pobre que no alcanza a deponer cosa alguna, pues los cortos réditos que percibe aún no sufragan para el sustento diario de las religiosas [...] debiendo gruesas cantidades que ha tomado en empréstito para lo preciso de la comunidad $^{75}$.

El depositario Carlos Manuel de Ledesma inició el trabajo de cotejo con las alhajas existentes y con los listados de aquellas que ya habían sido vendidas pero este proceso experimentó cierta demora debido a la enfermedad que padecía el oficial de pluma. Ante esta contingencia, el juez de Almoneda instó a aquellos funcionarios a culminar lo antes posible esta diligencia para atender la solicitud de las religiosas.

1816. AGN, Sección Archivo Anexo, Fondo Secuestros, tomo 3, f. 276 r.

73 Poblado indígena ubicado a pocas leguas al noroeste de la ciudad de Santa Fe.

74 El cura de Suba denuncia a la Junta de Secuestros haber comprado para el servicio de su iglesia varias alhajas de plata que existían en la casa de la moneda. Suba, 18-VIII-1815. AGN, Sección Archivo Anexo, Fondo Secuestros, tomo 2, 240-242.

75 El monasterio de Santa Clara solicita la restitución de las alhajas de su iglesia que extrajeron los insurgentes. Pamplona, 12-VI-1818. AGN, Sección Archivo Anexo, Fondo Asuntos Eclesiásticos, tomo 30, f. 538v. 
Los vecinos de Iscuandé en la costa Pacífica elevaron una queja por el robo perpetrado en la noche del 19 de enero de 1818 por los "piratas insurgentes" que desembarcaron en dos bergantines con la bandera de Buenos Aires. En el saqueo se llevaron varias alhajas de la iglesia y profanaron este recinto sagrado sin que los iscuandeños recibieran ningún auxilio del teniente de la cercana población de Micay. Según se reportó, los "bandidos" ingresaron a la ciudad y la desmantelaron por completo, además de lo cual "[...] entraron asimismo al santo templo, desarrajaron el sagrario y el depósito, sacaron la custodia con el Santo Santorum y el copón, de cuyas formas que en él habían, hasta ahora nada sabemos, llevaron todos los vasos sagrados y alhajas de plata del servicio de los altares, como es público y constante"76.

Gracias a las súplicas de los pobladores, se pudo conservar el Señor Sacramentado al ser guardado en una casa ubicada a la orilla del río mientras que los asaltantes se llevaron las joyas en un baúl que luego ocultaron en el monte. Al cura don Marcos Orejuela se le culpó de negligencia por no haber resguardado a tiempo estas piezas sagradas sabiendo de la inminente llegada de los piratas, según el reporte suministrado por los vigías militares de la ciudad. También se le juzgó por haber permitido que los vecinos las ocultaran y consumieran las hostias antes de que fueran objeto de sacrilegio por parte de los invasores pese a las oportunas advertencias que le hicieron algunos vecinos y el cura de Guapi.

Se intentó reconstruir el inventario de lo que habían sustraído los piratas, dentro de lo cual figuraba una corona grande dorada de Santa Bárbara, un sol o custodia con peana, una custodia de oro fino, tres cálices de plata y uno de ellos engastado en piedras, cuatro patenas, un cristo y una cruz de plata, un platillo de plata y sus vinajeras doradas, un incensario grande de plata, un relicario de plata dorado, un iris de la Virgen y su espada de plata, un clavo de plata del Cristo del Calvario, una diadema de plata, dos corazones de plata de San José, una corona de plata y media luna de la Virgen del Rosario. En el asalto resultaron quebrados los siguientes elementos: una cruz alta forrada de plata, tres espejos del sagrario y dos cilindros de cristal.

A los pocos días, las fuerzas españolas interceptaron las embarcaciones y recuperaron las joyas, algunas de las cuales fueron donadas al pueblo de David, en Panamá, que también había sido saqueado.

En consecuencia con esta problemática, el cabildo de Iscuandé solicitó apoyo al gobernador de la provincia de Popayán don José Solís para que, en aras del "consuelo espiritual", les fueran reintegradas las alhajas perdidas, así fuera a costa de los que tuvieron responsabilidad en el incidente. Se hacía énfasis en que el pueblo había quedado desamparado espiritualmente tras la desaparición de estas piezas sagradas. A este clamor se sumó también el procurador de la ciudad don José María Vallejos. Solís envió el caso a consideración del virrey Juan Sámano.

Por su parte, los habitantes del pueblo de David quisieron reafirmar su posesión sobre las alhajas que le habían sido donadas pero no se pudo atender esta petición porque, tras el cotejo realizado, se reconoció que pertenecían a Iscuandé pues los piratas no tenían dominio legítimo sobre ellas por no haber sido adquiridas legalmente.

76 El gobernador de Popayán acompaña la solicitud de los vecinos de Iscuandé sobre el robo que hicieron los piratas de su iglesia. Popayán, 19-I-1818. AGN, Sección Archivo Anexo, Fondo Historia, tomo 23, f. 631v. 
El fiscal que revisó el caso consideró que el cura de Iscuandé debía reponer aquellas alhajas faltantes por la responsabilidad que le competía en este asunto. Entre tanto, el gobierno virreinal impartió instrucciones para reforzar militarmente estas localidades y así evitar que se repitiera un asalto de esas dimensiones.

Sin lugar a dudas, el mayor número de reclamaciones se formalizaron durante el periodo de la Segunda República en busca de resarcimientos por contribuciones forzosas ordenadas por los gobernantes de la primera fase republicana. En estos casos concretos, los reclamos de los demandantes se canalizaron a través de la Comisión de Liquidación creada en 1821 y contaron con el beneficio adicional de recibir un pago de intereses por el sacrificio realizado a favor de la Patria.

Dentro del empréstito forzoso impuesto por el general republicano Antonio Nariño en febrero de 1814 a la iglesia catedral de Popayán para financiar la última fase de la expedición del Sur, fueron entregadas varias alhajas a la casa de la Moneda, siendo estimado su peso en 747 marcos. Hacia 1825 el cabildo eclesiástico de esta ciudad designó al Padre Santiago Pérez de Arroyo para que viajara a Bogotá a presentar formalmente la reclamación y en abril de 1826 la Comisión de Liquidación reconoció a favor de la catedral un total de 9.253 pesos, de lo cual 3.446 pesos correspondían a los intereses que habían corrido durante estos doce años ${ }^{77}$.

Todas las alhajas del convento hospital de San Juan de Dios de Cartagena habían sido recogidas en 1815 por el gobierno republicano para reducirlas a moneda y asegurar el pago a las tropas que resistían el sitio impuesto por el ejército español al mando del general Pablo Morillo. En noviembre de 1822, cuando los patriotas ya habían recuperado el poder, fray Salvador Forero, procurador de la Provincia de San Juan de Dios, solicitó le fueran restituidas estas piezas sagradas con la esperanza de que al menos se entregaran aquellas indispensables para la celebración de las ceremonias litúrgicas, para la administración de los santos sacramentos a los enfermos y para rendir culto a Dios.

La congregación religiosa se dedicó entonces a levantar el inventario de las alhajas entregadas en 1815. De los elementos de plata, sobresalían por su peso y valor: seis cálices, dos ciriales, dos atriles, dos campanas, una cruz procesional, seis candeleros y, principalmente, los canutos de las seis varas del palio que pesaban 81 marcos. Entre los objetos de oro, se registraron cuatro tejos, cuyo peso total era de 391 marcos. Entre las piedras preciosas se contabilizaron 50 esmeraldas, 353 topacios, 104 rubíes, 34 zafiros y muchas piedras de Francia, cuyo peso total fue de 209 marcos, siete onzas. Tres testigos fueron citados por las autoridades para certificar la veracidad de este inventario a fin de que coincidiera con aquellas alhajas que habían sido extraídas. De estos testigos quizás el más sensato en su concepto fue Enrique Rodríguez, quien confesó algunas dificultades afrontadas en este proceso de identificación:

Sin embargo de que al cabo de nueve años no es posible hacer individual memoria de las alhajas de plata que el convento hospital San Juan de Dios exhibió en la casa de amonedación, y más cuando allí no se atendía sino al peso que era cuanto se necesitaba para la cuenta, no obstante, certifico que hago fija memoria que entre

El señor doctor Santiago Arroyo por el cabildo eclesiástico de Popayán, deuda doméstica. Popayán, 4-IV-1822. BLAA, Sala de Libros Raros y Manuscritos, Documento n 1758 , ff. 1r-11v. 
las que se entregaron había muchas de las que constan en la nota de que hago reminiscencia porque habiéndolas visto sirviendo en la iglesia llamaron al tiempo de su recibo particularmente mi atención ${ }^{78}$.

Después de revisar el caso, en su dictamen del 17 de diciembre de 1823 el secretario de Hacienda don José María del Castillo y Rada aceptó que había que reconocer esta deuda y, por consiguiente, impartió las respectivas instrucciones a la Comisión de Liquidación. No fue sino al cabo de seis años cuando finalmente este órgano determinó pagar 4.318 pesos a favor del convento, conforme a lo estipulado en el inventario presentado.

Otra reclamación similar a las dos anteriores surgió a raíz de la orden dada en abril de 1816 por el general José Antonio Páez y el comandante de armas de la provincia de Casanare don Juan Nepomuceno Moreno, quienes comisionaron a fray Benigno Hurtado, cura de Morcote, para que extrajera de las iglesias de la provincia aquellas alhajas que fueran menos indispensables para el servicio del culto divino. En respuesta a este llamado, el 21 de este mes la iglesia de Pisba entregó un total de 312 onzas de plata dentro de lo cual sobresalían por su valor una custodia y una cruz alta, piezas que fueron fundidas y acuñadas para el socorro de las tropas republicanas ante la amenaza de la Reconquista española.

Hacia el mes de diciembre de 1825, el cura Domingo Antonio Vargas, vicario superintendente de la provincia de Casanare, solicitó se declarara en deuda doméstica pagable el valor de estas alhajas en vista del estado de indigencia del templo de Pisba y el escaso apoyo de los feligreses para el sostenimiento del culto divino. Curiosamente, la reclamación se demoró por no haber papel sellado pero finalmente, previa aprobación del tesorero fiscal de Hacienda, la Comisión de Liquidación decidió resarcir con 450 pesos, incluyendo los intereses ${ }^{79}$.

\section{Conclusiones}

El deterioro y destrucción de las alhajas contribuyó sin lugar a dudas a ahondar la crisis del estamento religioso en estos años de lucha independentista como parte del sistemático desmantelamiento de su patrimonio económico, material y espiritual. De alguna manera, la pérdida y destrucción de estas piezas sagradas significó también una pérdida incalculable de la riqueza cultural reflejada a través del dedicado trabajo de joyeros y plateros que ponían en práctica una tradición ancestral. Un ejemplo vivo de ello es la custodia de la Santísima Trinidad que perteneció al convento de San Francisco de la ciudad de Popayán y que aún se conserva pese a haber perdido su base original que fue fundida para financiar en 1814 la campaña militar del general Antonio Nariño ${ }^{80}$. Para los feligreses fue también un impacto a su devoción ancestral pues vieron cómo muchas de sus imágenes sagradas eran despojadas de sus adornos.

Paradójicamente, las alhajas y ornamentos que sobrevivieron a este periodo de guerra resultaron luego afectadas por las decisiones políticas asumidas por el naciente

\footnotetext{
${ }_{78}$ El convento hospital San Juan de Dios de Cartagena por las alhajas que se tomaron. Cartagena, 5-IX-1829. BLAA, Sala de Libros Raros y Manuscritos, Documento n 93, f. 11v.

79 Reclamo que hace el mayordomo de fábrica de la iglesia de Pisba, de deuda nacional doméstica de alhajas. Pisba, 9-XII-1825. BLAA, Sala de Libros Raros y Manuscritos, Documento nº 1765, ff. 1r-13r.

80 Fajardo, 2009: 43.
} 
gobierno libre. La ley del 28 de julio de 1821 ordenó la supresión de los conventos que contaran con menos de ocho religiosos y destinó preferentemente sus bienes y fondos para la dotación y subsistencia de los colegios o casas de educación ${ }^{81}$.

En respuesta a una consulta elevada el 10 de diciembre al Consejo de Gobierno, se precisó que las alhajas de oro, plata y otras que no fueran vasos sagrados, podían venderse para la educación pública, conforme a lo estipulado en la ley del 28 de julio. Entre tanto, las otras alhajas debían dejarse en los templos, entregándose debidamente inventariadas a los respectivos párrocos ${ }^{82}$.

Así entonces, frente al debilitamiento de la Iglesia, el gobierno republicano buscó consolidar su legitimidad y erigirse como máxima autoridad, lo cual implicaba mantener un mayor control sobre aquel estamento ${ }^{83}$ y avanzar progresivamente hacia el camino de la secularización. No obstante, en las décadas siguientes se agudizaría la polarización ideológica en torno al grado de influencia de la religión y de la moral católica en la sociedad colombiana, disputas que se manifestarían de una manera más acentuada en las luchas partidistas y en las guerras civiles que asolaron al país a lo largo del siglo $\mathrm{XIX}^{84}$, contexto en el que nuevamente las alhajas quedarían en medio del fragor del conflicto político y militar.

\section{Referencias bibliográficas}

Acuerdos. Acuerdos del Consejo de Gobierno de la República de Colombia, 18211824, tomo I. Bogotá: Biblioteca de la Presidencia de la República, 1988.

Álvarez Jiménez, Jairo. "Clero, pueblo y poder civil en el Caribe Colombiano: entre conflictos políticos y divergencias religiosas". Revista Amauta, no 15 (2010), 5571.

Ariza, Alberto O.P. El convento del Santo Ecce-homo, tomo II. Bogotá: Cooperativa Nacional de Artes Gráficas, 1966.

- Los Dominicos en Colombia. Bogotá: Ediciones Antropos, 1992.

Barriga del Diestro, Fernando. Finanzas de nuestra Segunda Independencia: apuntes económicos, financieros y numismáticos, tomo I. Bogotá: Universidad de Los Andes - Academia Colombiana de Historia, 2010.

Barriga Villalba, A. M. Historia de la Casa de la Moneda, tomo II. Bogotá: Banco de la República, 1969.

Bonilla, Heraclio (comp.). Pablo Morillo. Documentos de la Reconquista de Colombia. Transcripciones del Fondo Documental "Pablo Morillo". Bogotá: Centro Cultural y Educativo Español Los Reyes Católicos - Universidad Nacional de Colombia, 2011.

Borja Gómez, Jaime Humberto. Arte Sacro. 450 años. Arquidiócesis de Bogotá. Bogotá: Consuelo Mendoza Ediciones, 2012.

Bushnell, David. El Régimen de Santander en la Gran Colombia. Bogotá: El Áncora

\footnotetext{
Gaceta de la ciudad de Bogotá, n 125, 16-XII-1821, 403.

Acuerdos, 1988: 9-10.

Bushnell, 1985: 223.

González, 1985: 3-17.
} 
Editores, 1985.

Caballero, José María. Particularidades de Santafé. Bogotá: Biblioteca Popular de Cultura Colombiana, 1946.

Castrillón Arboleda, Diego. Batalla de Calibio. Popayán: Ejército Nacional, 1975.

Congreso. Congreso de las Provincias Unidas 1814-1816, tomo II. Bogotá: Biblioteca de la Presidencia de la República, 1988.

Cortés Guerrero, José David. "Balance historiográfico sobre las relaciones EstadoIglesia en Colombia desde la Independencia hasta finales del siglo XIX". Historia y Sociedad, $\mathrm{n}^{\mathrm{o}} 18$ (2010), 163-190.

Fajardo de Rueda, Marta. "La orfebrería en la gobernación de Popayán”. Ensayos. Historia y teoría del arte, $\mathrm{n}^{\circ} 17$ (2009), 25-43.

González, Fernán. Iglesia y Estado en Colombia durante el siglo XIX (1820-1860). Bogotá: Centro de Investigación y Educación Popular (CINEP), 1985.

Groot, José Manuel. Historia Eclesiástica y Civil de la Nueva Granada, tomo III, $2^{\mathrm{a}}$ edición. Bogotá: Casa Editorial de Medardo Rivas, 1891.

Hernández de Alba, Guillermo. "Sumarias de los procesos seguidos contra los clérigos patriotas". Boletín de Historia y Antigüedades, vol. XLIX, n ${ }^{\circ}$ 573-574 (1962), 345-436.

Instituto de Cooperación Iberoamericana (ICI). Orfebrería Hispanoamericana, siglos XVI-XIX. Madrid: Museo de Madrid, 1986.

Jurado Noboa, Fernando. Esclavitud en la Costa Pacifica. Iscuandé, Barbacoas, Tumaco y Esmeraldas. Siglo XVI al XIX. Quito: Centro Afro-Ecuatoriano, 1990.

Mantilla, Luis Carlos. Los Franciscanos en Colombia, tomo III, vol. 2. Bogotá: Ediciones de la Universidad de San Buenaventura, 2000.

Martínez Garnica, Armando - Gutiérrez Ardila, Daniel (eds.). La contrarrevolución de los pueblos de las Sabanas de Tolú y el Sinú (1812). Bucaramanga: Universidad Industrial de Santander, 2010.

Mesanza, Andrés. Apuntes y documentos sobre la Orden Dominicana en Colombia (de 1680 a 1930). Caracas: Editorial Sur-América, 1936.

Miguéliz Valcarlos, Ignacio. "Pérdida de las alhajas de plata de la iglesia de Navarra durante la guerra de la Independencia (1808-1814)". Príncipe de Viana, año LXXIII, no 256 (2012), 731-759.

Pacheco, Juan Manuel. "Constituciones Sinodales del Sínodo de 1606 celebradas por Don Bartolomé Lobo Guerrero". Ecclesiástica Xaveriana, vol. V (1955), 153-201.

— "La expulsión de los Jesuitas del Nuevo Reino de Granada". Revista de Indias, $\mathrm{n}^{\mathrm{o}}$ 113-114 (1968), 351-381.

Restrepo, José Manuel. Historia de la revolución de la República de Colombia en la América Meridional [1858], tomo I. Medellín: Editorial Universidad de Antioquia, 2009.

Rey-Márquez, Juan Ricardo. "Nacionalismos aparte: antecedentes republicanos de la iconografía nacional". En Las historias de un grito. Doscientos años de ser colombianos. Exposición conmemorativa del Bicentenario, editado por Museo Nacional de Colombia. Bogotá: Ministerio de Cultura, 2010, 9-15.

Rodríguez Maldonado, Carlos. Joaquín Matajudios. Orfebre y maestro platero santafereño 1775-1855. Bogotá: Editorial El Gráfico, 1945.

Rodríguez Plata, Horacio. La antigua provincia del Socorro y la Independencia. Bogotá: Editoriales Bogotá, 1963. 
Rodríguez Villa, Antonio. El teniente general don Pablo Morillo. Primer Conde de Cartagena, Marqués de la Fuerte (1778-1837), tomo I. Madrid: Tipografía de Fortanet, 1910.

Rueda Enciso, José Eduardo. "La parroquia de Nunchía: el auge de una población llanera post expulsión de los jesuitas 1770-1825". Historelo, vol. 5, no 9 (2013), 103-145.

Tovar Pinzón, Hermes. "Guerras de opinión y represión en Colombia durante la Independencia (1810-1820)". Anuario Colombiano de Historia Social y de la Cultura, $\mathrm{n}^{\circ} 11$ (1983), 187-232.

Villanueva, Antolín. Los ornamentos sagrados en España. Su evolución histórica y artística. Barcelona: Editorial Labor, 1935. 